The Chittagong Univ. J. B. Sci., Vol. 3(1 \&2): pp. 87-94, 2008.

\title{
ANTIBACTERIAL AND ANTIFUNGAL ACTIVITY OF CRUDE EXTRACTS OF PLUMERIA RUBRA L.
}

\author{
LAILA JARIN, MD. SHAFIQUR RAHMAN AND M. N. ANWAR * \\ Department of Microbiology, University of Chittagong, Chittagong- 4331, Bangladesh.
}

\begin{abstract}
Petroleum ether, carbon tetrachloride, chloroform and ethyl acetate extracts of Plumeria rubra leaves were studied for their antimicrobial activities against eleven human pathogenic bacteria, viz., Shigella dysenteriae, S. sonnei, Salmonella typhi, S. paratyphi, Bacillus subtilis, B. megaterium, B. cereus, Staphylococcus aureus, Pseudomonas aeruginosa, Escherichia coli and Vibrio cholerae and four human pathogenic fungi, viz., Aspergillus niger, A. ochraceus, A. ustus and Candida albicans using disc diffusion and poisoned food method, respectively. Chloroform and ethyl acetate extract exhibited moderate to good antibacterial and antifungal activity against all the pathogens tested. The ethyl acetate extracts exhibited the largest zone of inhibition $(25 \mathrm{~mm}$ in diameter with $2000 \mu \mathrm{g} /$ disc extract) against $E$. coli. The highest inhibition of fungal radial mycelial growth (62.00\% with $100 \mu \mathrm{g}$ extract $/ \mathrm{ml}$ medium) was recorded against A. ustus with ethyl acetate extract. The MICs were determined by broth macrodilution technique. The ethyl acetate extract exhibited the lowest MIC (750 $\mu \mathrm{g} / \mathrm{ml}$ ) against $E$. coli. However, for fungi the lowest MIC was $500 \mu \mathrm{g} / \mathrm{ml}$ against A. ustus with the same extract.
\end{abstract}

Key words: Antimicrobial activity, crude extract, leaf, Plumeria rubra.

\section{INTRODUCTION}

Various plant species have been serving as the natural source of drugs and medicines from the beginning of civilization. The use of, and search for drugs and dietary supplements derived from plants have accelerated in recent years. Traditional healers have long used plants to prevent or cure infectious conditions and western medicine is trying to duplicate their successes. Plants are rich in a wide variety of secondary metabolites, such as tannins, terpenoids, alkaloids, saponins, glycosides, quinolines, essential oils and flavonoids, which have been found in vitro to have antimicrobial properties (Ahmed et al. 2002, Aureli et al.1992, Rahman et al. 1999). They are capable of mitigating and curing human

\footnotetext{
* Corresponding author.
} 
sufferings, healing wounds, cuts, burns and other antimicrobial source. Microorganisms have developed resistance to many antibiotics and this has created immense clinical problem in the treatment of infectious diseases (Davis 1994). This situation forced scientists to search for new antimicrobial substances from various sources. Now-a-days, the natural products have been accepted as important sources of biologically active antimicrobial substances, and the major sources of which are still left undiscovered. But a few works have been done in this field in Bangladesh(Rahman et al.1999, Ahmed et al.1999).

Plumeria rubra L. is a small tree with crooked trunk, rough bark and pink fragrant flowers, which belongs to the family Apocynaceae. It grows everywhere in Bangladesh as an ornamental plant. Plant principally contains triterpenes, plumeric acid, glycosides, plumieride and methyl ester. Juice of leaves is used as poultice to swelling and stem bark is used in diarrhoea and piles (Ghani 1998). Considering above mentioned facts, the present work has been undertaken to observe antimicrobial activity of extracts of P. rubra.

\section{MATERIALS AND METHODS}

\section{Collection and extraction of plant material}

Leaves of Plumeria rubra were collected in fresh condition from the Chittagong University campus, Chittagong, Bangladesh. The collected and cleaned samples were cut into small pieces $(1-2 \mathrm{~cm})$, dried in air to make it suitable for grinding. The samples were ground to fine powder mechanically and then $50 \mathrm{~g}$ of the dried powder was kept steeped for 72 hours in petroleum ether, chloroform, ethyl acetate and carbon tetrachloride. The extracts thus obtained separately were filtered, centrifuged at $5000 \mathrm{rpm}$ for 20 minutes and concentrated to a gummy material under reduced pressure at $50^{\circ} \mathrm{C}$ by rotary vacuum evaporator. The gummy materials were then collected in small vials and dried to obtain the crude extract.

\section{Test organisms}

The crude extracts obtained from Plumeria rubra were tested for their antibacterial activity against ten human pathogenic bacteria, viz., Shigella dysenteriae AE 14396, S. sonnei CRL.(ICDDR,B), Salmonella typhi AE 14612, S. paratyphi AE 14613 , Bacillus subtilis BTCC 17, B. cereus BTCC 19, B. megaterium BTCC 18, Staphylococcus aureus ATCC 6538, Pseudomonas aeruginosa CRL(ICDDR'B), Escherichia coli ATCC 25922 and Vibrio cholerae $\mathrm{AE} 14748$, and four human pathogenic fungi viz., Aspergillus niger BTCC 504, A. ochraceus BTCC 515, A. ustus BTCC 503 and Candida albicans BTCC 493. 


\section{ANTIBACTERIAL AND ANTIFUNGAL ACTIVITY OF PLUMERIA RUBRA}

The test organisms were collected from Department of Microbiology, University of Chittagong, Bangladesh.

\section{Determination of antimicrobial activity}

The in vitro antibacterial and antifungal activities of the crude extract of the plant were determined by disc diffusion method (Bauer et al. 1966) and poisoned food technique (Miah et al. 1990), respectively. Mueller-Hinton (agar and broth) medium was used for culture of bacteria and Sabouraud (agar and broth) medium was used for fungi. A $10 \%$ solution of the crude extract was used as the test material. All the results were compared with the standard antibacterial antibiotic

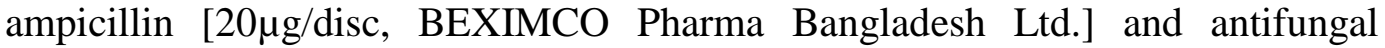
antibiotic nystatin $[100 \mu \mathrm{g} / \mathrm{ml}$ medium, BEXIMCO Pharma Bangladesh Ltd.]. MIC of the crude extract was determined by macro-dilution broth technique (Jones et al. 1985).

\section{RESULTS AND DISCUSSION}

The crude extracts (petroleum ether, chloroform, ethyl extract and carbon tetrachloride extracts) obtained from Plumeria rubra were screened for their antibacterial activity against eleven human pathogenic bacteria and compared to that of standard antibacterial antibiotic ampicillin. The results of the sensitivity test are presented in Table 1. Among the four solvent extracts, only chloroform and ethyl acetate extracts showed antibacterial activity. The chloroform and ethyl acetate extracts exhibited good antibacterial activity against the test organisms tested. But crude extracts of petroleum ether and carbon tetrachloride did not show antibacterial activity at a concentration of $2000 \mu \mathrm{g} / \mathrm{disc}$ extract. The ethyl acetate extract exhibited the largest zone of inhibition $(25 \mathrm{~mm}$ in diameter with $2000 \mu \mathrm{g} / \mathrm{disc}$ extract) against $E$. coli. The standard antibiotic ampicillin $(20 \mu \mathrm{g} / \mathrm{disc})$ was also found to be active against all the bacteria tested. Similar antibacterial activity of other plant extracts has been reported previously (Sarker et al. 1991, Rojas et al. 1992, Brantner and Grein 1994, Rahman et al. 1998, Ahmed et al. 1999).

The antifungal activity of the crude extract $(100 \mu \mathrm{g} / \mathrm{ml}$ medium) against four human pathogenic fungi was studied and compared with that of standard antifungal antibiotic nystatin. The results of the inhibition of radial mycelial growth of fungi are summarized in Table 2. 
LAILA JARIN ET AL..

TABLE 1: ANTIBACTERIAL ACTIVITY OF CRUDE EXTRACTS FROM PLUMERIA RUBRA.

\begin{tabular}{|c|c|c|c|c|c|}
\hline \multirow{2}{*}{ Name of bacteria } & \multicolumn{4}{|c|}{$\begin{array}{l}\text { Diameter of inhibition zone in mm. } \\
\text { (Crude extract } 2000 \mu \mathrm{g} / \mathrm{disc})\end{array}$} & \multirow{2}{*}{$\begin{array}{l}\text { Ampicillin* } \\
20 \mu \mathrm{g} / \mathrm{disc}\end{array}$} \\
\hline & $\begin{array}{l}\text { Petroleum } \\
\text { ether }\end{array}$ & $\begin{array}{c}\text { Carbon } \\
\text { tetrachloride }\end{array}$ & Chloroform & Ethyl actate & \\
\hline Bacillus subtilis & - & - & 10 & 19 & 19 \\
\hline B. megaterium & - & - & 12 & 12 & 16 \\
\hline B. cereus & - & - & 14 & 20 & 18 \\
\hline Staphylococcus aureus & - & - & 18 & 22 & 22 \\
\hline E. coli & - & - & 19 & 25 & 10 \\
\hline Vibrio cholerae & - & - & 14 & 14 & 15 \\
\hline Shigella dysenteriae & - & - & 10 & 11 & 22 \\
\hline S. sonnei & - & - & 13 & 16 & 20 \\
\hline Salmonella typhi & - & - & 12 & 16 & 20 \\
\hline S. paratyphi & - & - & 14 & 15 & 17 \\
\hline Pseudomonas & - & - & 10 & 11 & 15 \\
\hline aeruginosa & & & & & \\
\hline
\end{tabular}

*Standard antibacterial antibiotic

TABLE 2: ANTIFUNGAL ACTIVITY OF THE CRUDE EXTRACTS FROM PLUMERIA RUBRA.

Percentage inhibition of fungal mycelial growth ${ }^{\mathrm{a}}$

Name of fungi $(100 \mu \mathrm{g} / \mathrm{ml}$ medium $)$

\begin{tabular}{lccccc}
\multicolumn{5}{c}{ ether } & tetrachloride \\
\hline Aspergillus niger & - & - & 23.00 & 26.00 & 62.50 \\
A. ochraceus & - & - & 42.00 & 50.00 & 68.00 \\
A. ustus & - & - & 50.00 & 62.00 & 72.00 \\
Candida albicans & - & - & 50.00 & 38.00 & 78.50 \\
\hline
\end{tabular}

* Standard antifungal antibiotic ; Minus(-) mean no growth;

${ }^{\mathrm{a}}$ Growth measured- radial growth in $\mathrm{mm}$. 


\section{ANTIBACTERIAL AND ANTIFUNGAL ACTIVITY OF PLUMERIA RUBRA}

From Table 2, it appeared that the petroleum ether and carbon tetrachloride extracts have no antifungal activity at a concentration of $100 \mu \mathrm{g} / \mathrm{ml}$ medium. On the other hand, chloroform and ethyl acetate extract of $P$. rubra inhibited the radial mycelial growth of all the test fungi at a concentration of $100 \mu \mathrm{g} / \mathrm{ml}$ medium. The highest inhibition (62.0\%) of fungal radial mycelial growth was recorded against A. ustus with ethyl acetate extract at a concentration of 100 $\mu \mathrm{g} / \mathrm{ml}$ medium. Antifungal antibiotic nystatin $(100 \mu \mathrm{g} / \mathrm{ml}$ medium $)$ exhibited inhibitions of radial mycelial growth of all the four fungi. Similar antifungal activities on plant extracts of other plants have also been previously reported (Naidu and John 1981, Shetty and Shetty 1987, Miah et al. 1990, Stange et al. 1993, Anwar et al. 1994).

The MIC values of the crude extracts obtained from $P$. rubra leaf are summarized in Table 3. It appeared that the chloroform and ethyl acetate extract exhibited the MIC values from $750 \mu \mathrm{g} / \mathrm{ml}$ to $2000 \mu \mathrm{g} / \mathrm{ml}$ against the bacterial pathogens. But petroleum ether and carbon tetrachloride extract did not show MIC up to the extract concentration of $2500 \mu \mathrm{g} / \mathrm{ml}$. The lowest MIC $(750 \mu \mathrm{g} / \mathrm{ml})$ was recorded against $E$. coli with ethyl acetate extract. In case of fungi, chloroform and ethyl acetate extracts exhibited MICs from $500 \mu \mathrm{g} / \mathrm{ml}$ to 2000 $\mu \mathrm{g} / \mathrm{ml}$ against the fungal pathogens. The lowest MIC $(500 \mu \mathrm{g} / \mathrm{ml})$ was recorded against $A$. ustus with ethyl acetate extract. 
LAILA JARIN ET AL..

TABLE 3: MICS OF CRUDE EXTRACTS FROM PLUMERIA RUBRA.

\begin{tabular}{lcccc}
\hline Bacteria / fungi & \multicolumn{4}{c}{ MIC (Crude extract $\mu \mathrm{g} / \mathrm{ml}$ medium) } \\
\cline { 2 - 5 } A. Bacteria: & Pet. ether & C. tetrachloride & Chloroform & Ethyl acetate \\
Bacillus subtilis & $\mathrm{NF}$ & $\mathrm{NF}$ & 2000 & 1500 \\
B. megaterium & $\mathrm{NF}$ & $\mathrm{NF}$ & 1500 & 2000 \\
B. cereus & $\mathrm{NF}$ & $\mathrm{NF}$ & 1500 & 1000 \\
Staphylococcus aureus & $\mathrm{NF}$ & $\mathrm{NF}$ & 2000 & 1000 \\
E. coli & $\mathrm{NF}$ & $\mathrm{NF}$ & 2000 & 750 \\
Vibrio cholerae & $\mathrm{NF}$ & $\mathrm{NF}$ & 1500 & 1000 \\
Shigella dysenteriae & $\mathrm{NF}$ & $\mathrm{NF}$ & 2000 & 1500 \\
S. sonnei & $\mathrm{NF}$ & $\mathrm{NF}$ & 1500 & 1000 \\
Salmonella typhi & $\mathrm{NF}$ & $\mathrm{NF}$ & 1500 & 1500 \\
S. paratyphi & $\mathrm{NF}$ & $\mathrm{NF}$ & 1500 & 2000 \\
Pseudomonas aeruginosa & $\mathrm{NF}$ & $\mathrm{NF}$ & 1500 & 1000 \\
B. Fungi: & & & & \\
Aspergillus niger & $\mathrm{NF}$ & $\mathrm{NF}$ & 2000 & 1000 \\
A. ochraceus & $\mathrm{NF}$ & $\mathrm{NF}$ & 1500 & 750 \\
A. ustus & $\mathrm{NF}$ & $\mathrm{NF}$ & 1000 & 500 \\
Candida albicans & $\mathrm{NF}$ & $\mathrm{NF}$ & 750 & 750 \\
\hline NF- no & & & & \\
\hline
\end{tabular}

$\mathrm{NF}$ - not found up to $2500 \mu \mathrm{g} / \mathrm{ml}$

The present investigation confirms that there are antibacterial and antifungal properties in the crude extract of Plumeria rubra leaf. However, it is important to point out that crude extract such as this needs to be further processed to obtain pure compound(s) which can then be tested for antimicrobial activity. 
ANTIBACTERIAL AND ANTIFUNGAL ACTIVITY OF PLUMERIA RUBRA

\section{REFERENCES}

AHMED, A. M .A., RAHMAN, M. S. AND ANWAR, M. N. 1999. Antimicrobial activity of extracts and crude alkaloids of Polyalthia longifolia (Sonn.) Thw. stem bark. The Chittagong Univ. J. Sci. 23(1) : 53-56.

AHMED, A. M .A., RAHMAN, M. S. AND ANWAR, M. N. 2002. Antimicrobial activity of extracts and crude alkaloids isolated from the leaf of Adhatoda vasica Nees. Bangladesh J. Life Sci. 15(2) : 125-128.

ANWAR, M. N., SINGHA, P., BEGUM J. AND CHOWDHURY, J. U. 1994. Antifungal activity of some selected plant extracts on phytopathogenic fungi. Bangladesh J. Life Sci. 6(2): 23-26.

AURELI, P., COSTANTINI, A. AND ZOLEA, S. 1992. Antimicrobial activity of some plant essential oils against Listeria monocytogenes. J. Food Prod. 55: 344-348.

BAUER, A. W., KIRBY, M. M., SHERRIS, J. C. AND TURCK, M. 1966. Antibioticsusceptibility testing by a standardized single disc method. Amer. J. Clin. Path. 45: 493-496.

BRANTNER, A. AND GREIN, E. 1994. Antibacterial activity of plant extracts used externally in traditional medicine. J. Ethnopharmacol. 44:35-40.

DAVIS, J. 1994. Inactivation of antibiotics and the dissemination of resistance genes. Scienc. 264: 375-382.

GHANI, A. 1998. Medicinal plants of Bangladesh: Chemical constituents and Uses(First ed.). Asiatic Society of Bangladesh. pp. 267-268

JONES, N. R., BARRY, L. A., GAVAN, L. T. AND WASHINGTON, J. A. 1985. Manual of Clinical Microbiology( $4^{\text {th }}$ ed.). American Society for Microbiology, Washington D. C. pp 972- 976.

MIAH, M. A. T., AHMED, H. U., SHARMA, N. R., ALI, A. AND MIAH, S. A. 1990. Antifungal activity of some plant extracts. Bangladesh J. Bot. 19(1): 5-10.

NAIDU, A. D. AND JOHN, V. T. 1981. In vitro inhibition of the rice fungal pathogens by extracts from higher plants. Int. Rice Res. Newsl. 6(5): $12-14$.

RAHMAN, M. S., ANWAR, M. N. AND CHOWDHURY, A. Z. M. S. 1999. Antibacterial activity of Secondary metabolites from Holarrhena antidysenterica stem bark. Bangladesh J. Microbiol. 16(2): 101-105. 
RAHMAN, M. S., BEGUM, J., CHOWDHURY, J. U. AND ANWAR, M. N. 1998. Antimicrobial activity of Holarrhena antidysenterica against Salmonella typhi. The Chittagong Univ. J. Sci. 22(1) : 111-112.

ROJAS, A., HERNANDEZ, L., PEREDA-MIRANDA, R. AND MATA, R.. 1992. Screening for antimicrobial activity of crude drug extracts and pure natural products from Mexican medicinal plants. $J$. Ethnopharmacol. 35:275-283.

SARKAR, S. D., MUNIRUZZAMAN, S. AND KHAN, S. I., 1991. Antimicrobial activity of Piper Chaba Hunter (Chui). Bangladesh J. Bot. 20(2): 179-182.

SHETTY, S. A. AND SHETTY, H. S. 1987. Control of seed borne fungal pathogens of paddy using Strychnos nux-vomica extract. Oryza. 24: 153159.

STANGE, R. R., MIDLAND, S. L., ECKERT, J. W. AND SIMS, J. J. 1993. An antifungal compound produced by grapefruit and Valencia orange after wounding of the peel. J. Nat. Prod. 56:1627-1629.

Manuscript received on 11.1.08; Accepted on 26.6. 08

The Chittagong University Journal of Biological Sciences, Vol. 3(1 \& 2 ): pp. 87-94, 2008. 